\title{
Growth, Sporulation and Production of Bioactive Compounds by Bacillus subtilis R14
}

\author{
André Lacerda Ulysses de Carvalho ${ }^{1}$, Fábio Henrique Portella Corrêa de Oliveira ${ }^{1}$, Rosa \\ de Lima Ramos Mariano ${ }^{2}$, Ester Ribeiro Gouveia ${ }^{1}$ and Ana Maria Souto-Maior ${ }^{1 *}$ \\ ${ }^{1}$ Departamento de Antibióticos; Universidade Federal de Pernambuco; Cidade Universitária; 50670-901; Recife - \\ PE - Brasil. ${ }^{2}$ Departamento de Agronomia/Fitossanidade; Universidade Federal Rural de Pernambuco; Dois \\ Irmãos; 52171-030; Recife - PE - Brasil
}

\begin{abstract}
The physiology of $\mathrm{B}$. subtilis R14 was investigated in minimal medium under excess-oxygen and oxygen-limited conditions. Growth and efficient sporulation could be achieved in excess-oxygen culture on medium with readily metabolizable carbon and nitrogen sources, which allowed high growth rate and high biomass yield. A short transition phase between the exponential growth and sporulation could be attained by formulating a medium with a well-balanced $\mathrm{C} / \mathrm{N}$ ratio. Under oxygen-limitation, but in the presence of essential nutrients (i.e. excess-nutrient cultivation), B. subtilis R14 produced bioactive compounds, which showed activity against several phytopathogenic bacteria. Under anaerobic condition, the organism did not grow neither through fermentation nor anaerobic respiration. However, addition of pyruvate to the medium allowed its growth through fermentation and anaerobic respiration. The knowledge acquired in this work could be relevant both for the design of a production process as well as for the formulation of an effective commercial biocontrol product.
\end{abstract}

Key words: Bacillus subtilis, batch cultivation, oxygen availability, antimicrobial activity

\section{INTRODUCTION}

The genus Bacillus is one of the most utilized in the biocontrol of phytopathogens. This genus comprehends a heterogeneous group of Grampositive, aerobic or facultative anaerobic, endospore-forming bacteria (Fritze, 2004). The endospores are thermotolerant structures, resistant to dryness, ultraviolet radiation and organic solvents. These properties, associated to the ability of producing peptide antibiotics, contribute to its utilization to the biocontrol of several root and foliar diseases (Backman et al., 1997; Kloeper, 1997; Melo, 1998; Jacobsen et al., 2004; Schisler et al., 2004;). Bacilli control the bacteria that cause the plant disease through a variety of mechanisms of action, such as competition, systemic resistance induction and antibiotic production. The mechanism of antibiosis has been shown to be one of the most important (Thomashow and Weller, 1996). Among several peptide antibiotics, they produce lipopeptides, which are amphiphilic compounds with surfactant activity (Zuber et al., 1993).

Peptide antibiotics are composed of amino acids, but they often show little similarity to geneencoded polypeptides in terms of structure and mechanism of their biosynthesis (Zuber and

\footnotetext{
*Author for correspondence: soutomaior@ufpe.br
} 
Marahiel, 1997). Several strains of B. subtilis produce cyclic lipopeptides, among them surfactin, which is one of the most powerful biosurfactant known (Mulligan, 2004). Surfactin behaves as a very powerful surfactant because of its amphiphilic nature, with a polar amino acid head and a hydrocarbon chain. Transcription of the srfA operon is the major point of regulation of surfactin production, and it has turned out to involve a complex array of controlling elements including autoregulation, phosphorylation cascades, extracelullar signaling, and interplay with the regulation of different developmental pathways (Chater and Bibb, 1997).

B. subtilis R14 is an epiphytic isolate obtained from the surface of cabbage leaves (Brassica oleraceae var. capitata L. cv. Midori) (Assis et al., 1996; 1997). The efficiency of this isolate as a biocontrol agent was investigated against the black rot of crucifers, caused by Xanthomonas campestris pv. campestris, and the bacterial fruit blotch of melon, caused by Acidovorax avenae subsp. citrulli. In greenhouse experiments, the isolate eliminated the black rot of kale when tested against three isolates of $X$. campestris pv. campestris in all application periods tested (Assis et al., 1996). When submitted to field tests, this isolate had its efficiency corroborated, reducing $73 \%$ of the disease on cabbage (Assis et al., 1997). The control of the bacterial fruit blotch was investigated in vivo by treating the infected yellow melon seeds with broths of B. subtilis R14 cultivation (Santos et al., 2006). The treatments, with and without cells, showed no significant difference, indicating that the disease reduction occurred due to the presence of bioactive compounds produced during the cultivation. The mechanism of antibiosis was confirmed in vitro against nine strains of $X$. campestris pv. campestris, and the compounds produced were characterized as lipopeptides (Monteiro et al., 2005).

The production of secondary metabolites is normally associated with the bacterium's response to a growth-limiting environment. Faced with the depletion of essential nutrients, $B$. subtilis can adopt several responses, including motility, secretion of extracellular enzymes, competence for genetic transformation, antibiotic production, and finally sporulation. Depending on the environmental signal, one or more of these alternative processes can be stimulated or inhibited
(Smith, 1993). The actual choice depends upon the activity of an elaborated signal transduction network, which ultimately affects two key transcription factors, Spo0A and AbrB (Phillips and Strauch, 2002). In B. subtilis R14, the production of bioactive compounds was observed in batch cultivation on complex medium under oxygen limitation (Monteiro et al., 2005).

In this work, the physiology of B. subtilis R14 was investigated on defined growth media in excessoxygen and oxygen-limited batch cultures to identify stimuli for lipopeptide synthesis and sporulation. Both spores and lipopeptides are products of interest for the development of a commercial biological control agent. Furthermore, the bioactivity of compounds produced by $B$. subtilis R14 was investigated in vitro against several important phytopathogenic bacteria. Bacterial fruit blotch (Acidovorax avenae subsp. citrulli) is the main constraint for the cultivation of melon, watermelon and other cucurbits in the world and in Brazil, where it can cause losses in the production between $40-50 \%$, reaching up to $100 \%$ in the rainy season (Sales Júnior and Menezes, 2001). Crown gall (Agrobacterium tumefaciens) affects the plants belonging to 140 genera of more than 60 families. Infected plants with tumors at their crowns or on their main roots have reduced yields and may die (Agrios, 1997). Fire blight of apple and pear (Erwinia amylovora) does not occur in Brazil. However, in United States, it is only managed by the combination of several control measures and antibiotic applications leading to the development of resistant bacterial strains (Agrios, 1997). Soft rot (Pectobacterium carotovorum) on several hosts occurs in the field, in transit, and especially in storage. It reduces the market value of crops and increase the expenses for preventive measures (Agrios, 1997). Bacterial wilt (Ralstonia solanacearum) of potato, tomato and many other hosts is also one of the most important plant diseases worldwide. The high variability of the pathogen allied to the colonization of the plant vascular system make its control extremely difficult (Agrios, 1997). Black rot of crucifers (Xanthomonas campestris pv. campestris) is transmitted by the seeds and often causes severe losses (Agrios, 1997). Bacterial canker (X. campestris pv. viticola) is the main bacteriosis occurring in grapevine in Brazil, especially in the São Francisco Valley, where it constrains the 
cultivation of susceptible cultivars such as Red Globe, Itália, Festival and Benitaka, among other (Nascimento and Mariano, 2004).

\section{MATERIALS AND METHODS}

\section{Microorganism}

B. subtilis R14, isolated from the surface of cabbage (B. oleraceae var. capitata L. cv. Midori) leaves, was used in this work. The microorganism belongs to the Culture Collection of the Laboratory of Phytobacteriology of the Federal Rural University of Pernambuco (Brazil). The isolate was preserved on nutrient agar slants at $5^{\circ}$ $\mathrm{C}$ and subcultured every three months during this work.

\section{Cultivation media}

For excess-oxygen cultivation, the medium consisted of (per liter of distilled water): glucose, $10 \mathrm{~g} ; \quad\left(\mathrm{NH}_{4}\right)_{2} \mathrm{SO}_{4}, 2 \mathrm{~g} ; \mathrm{K}_{2} \mathrm{HPO}_{4}, 13.6 \mathrm{~g}$; $\mathrm{MgSO}_{4} \cdot 7 \mathrm{H}_{2} \mathrm{O}, 0.2 \mathrm{~g}$; trace elements solution, 10 $\mathrm{mL}$. The trace elements solution consisted of (per liter of distilled water): $\mathrm{CaCl}_{2}, 0.42 \mathrm{~g}$; $\mathrm{FeSO}_{4} \cdot 7 \mathrm{H}_{2} \mathrm{O}, 2.29 \mathrm{~g} ; \mathrm{MnCl}_{2} \cdot 4 \mathrm{H}_{2} \mathrm{O}, 0.10 \mathrm{~g} ; \mathrm{ZnCl}_{2}$, $0.17 \mathrm{~g} ; \mathrm{CuCl}_{2}, 0.03 ; \mathrm{CoCl}_{2} \cdot 6 \mathrm{H}_{2} \mathrm{O}, 0.06$; and $\mathrm{Na}_{2} \mathrm{MoO}_{4} \cdot 2 \mathrm{H}_{2} \mathrm{O}, 0.06 ; \mathrm{pH} 7$.

For anaerobic cultivation, performed in test tubes, the medium was buffered and glucose concentration was reduced to minimize $\mathrm{pH}$ variation. The medium consisted of (per liter of distilled water): glucose, $5 \mathrm{~g}$; $\left(\mathrm{NH}_{4}\right)_{2} \mathrm{SO}_{4}, 4 \mathrm{~g}$; $\mathrm{K}_{2} \mathrm{HPO}_{4}, 13.6 \mathrm{~g}, \mathrm{KH}_{2} \mathrm{PO}_{4}, 4 \mathrm{~g} ; \mathrm{MgSO}_{4} .7 \mathrm{H}_{2} \mathrm{O}, 0.2$ g. Growth was also investigated on medium containing a mixture of ammonium and nitrate: $\mathrm{NaNO}_{3}, 2 \mathrm{~g}$, and $\left(\mathrm{NH}_{4}\right)_{2} \mathrm{SO}_{4}, 2 \mathrm{~g}$; and on medium containing nitrate as the sole nitrogen source: $\mathrm{NaNO}_{3}, 4$ g. Furthermore, cultivations were also performed with the addition of sodium pyruvate $(5 \mathrm{~g})$ to all the investigated media. Parallel aerobic cultures were also carried out in large diameter test tubes as control experiments. The tubes were placed in a rotatory shaker at $250 \mathrm{rpm}$.

Since biomass yield was expected to decrease during oxygen-limited cultivation, the concentrations of glucose and ammonium sulphate were increased to (per liter of distilled water): glucose, $40 \mathrm{~g}$; $\left(\mathrm{NH}_{4}\right)_{2} \mathrm{SO}_{4}, 8 \mathrm{~g}$. This allowed the production of bioactive compounds at detectable levels. Higher concentrations were not used to avoid the substrate inhibition. Growth was also investigated on medium containing a mixture of ammonium and nitrate: $\mathrm{NaNO}_{3}, 4 \mathrm{~g}$, and $\left(\mathrm{NH}_{4}\right)_{2} \mathrm{SO}_{4}, 4 \mathrm{~g}$; and on medium containing nitrate as the sole nitrogen source: $\mathrm{NaNO}_{3}, 8 \mathrm{~g}$.

\section{Cultivation conditions}

Inocula were grown in Fernbach flasks on glucose/ $\left(\mathrm{NH}_{4}\right)_{2} \mathrm{SO}_{4}$ medium in a rotatory shaker (model C25KC, New Brunswick Scientific), at $37^{\circ}$ $\mathrm{C}$ and $250 \mathrm{rpm}$, and $5 \%(\mathrm{v} / \mathrm{v})$ was used to inoculate the bioreactor. The cultivations were performed in an instrumented 4-liter workingvolume batch bioreactor (BiofloIII, New Brunswick Scientific). For excess-oxygen culture, the aeration and agitation rates were kept at $1 \mathrm{vvm}$ and $700 \mathrm{rpm}$, respectively, and cultivations were carried out at $30^{\circ} \mathrm{C}$ and $37^{\circ} \mathrm{C}$. For oxygen-limited culture, no forced aeration was used and the agitation was reduced to $300 \mathrm{rpm}$. Cultivations were carried out at $37{ }^{\circ} \mathrm{C}$ in this case. All the experiments were performed in duplicates.

For anaerobic condition, the cultivations were not carried out in the bioreactor, but in test tubes, which were incubated at $37{ }^{\circ} \mathrm{C}$ in anaerobic Gaspak jars under an $\mathrm{H}_{2}-\mathrm{CO}_{2}$ atmosphere. In this case, the experiments were made in triplicates.

\section{Antimicrobial activity of bioactive compounds}

Bioactive compounds produced during oxygenrestricted cultivation were tested against the phytopathogenic bacteria listed in Table 1, where the respective plant disease was specified. A sample from one of the cultivations was passed through a C-18 column to recover the bioactive compounds, which were eluted with methanol, and then tested against all the listed bacteria. The activity test was performed as described in the analytical methods below.

\section{Analytical methods}

Biomass concentration was determined spectrophotometrically at $600 \mathrm{~nm}$ (Hewlett Packard 8453). Spore concentration was expressed as colony forming units (CFU) per $\mathrm{mL}$, after leaving the sample at $80{ }^{\circ} \mathrm{C}$ for $15 \mathrm{~min}$, diluting, and plating on nutrient agar medium. Glucose and $\left(\mathrm{NH}_{4}\right)_{2} \mathrm{SO}_{4}$ concentrations were assayed utilizing enzymatic kits (Gold Analisa; glucose-PP and urea UV-PP, respectively). Antimicrobial activity was determined using the agar diffusion method. Samples of $20 \mu \mathrm{l}$ and discs of $6 \mathrm{~mm}$ were used to perform the assays. The activity was expressed as the diameter of the inhibition halo in millimeters 
$(\mathrm{mm})$. To quantify the production of bioactive compounds during the cultivations, the phytopathogenic bacterium Agrobacterium tumefaciens was used as test microorganism, since preliminary studies had shown that, among the phytopathogenic bacteria investigated in this study, it was the most sensitive to the compounds produced by $B$. subtilis R14.

Table 1 - Phytopathogenic bacteria and respective plant disease.

\begin{tabular}{ll}
\hline Microorganism & Disease \\
\hline Acidovorax avenae subsp. citrulli & Bacterial fruit blotch of melon \\
Agrobacterium tumefaciens & Crown gall on several hosts \\
Erwinia amylovora & Fire blight of apple and pear \\
Pectobacterium carotovorum & Soft rot on several hosts \\
Ralstonia solanacearum RS13 bv.1 & Bacterial wilt of potato \\
$R$. solanacearum RS103 bv.1 & Bacterial wilt of tomato \\
Xanthomonas campestris pv. campestris & Black rot of crucifers \\
$X$. campestris $p v$ viticola & Bacterial canker of grapevine \\
\hline
\end{tabular}

\section{RESULTS AND DISCUSSION}

Many biocontrol agents are difficult to formulate as products. The sporulating Gram-positive bacteria, such as Bacillus and Streptomyces, offer biological solutions to the formulations problems (Emmert and Handelsman, 1999). The endospores are thermotolerant structures and resistant to dryness, ultraviolet radiation and organic solvents. These properties, associated to the ability of producing peptide antibiotics, contribute to Bacillus utilization in commercial formulations for the biocontrol of several plant diseases. When producing biomass of Bacillus spp. for biological control, the production should be designed to maximize the production of efficacious spores rather than vegetative cells. On the other hand, the physiology of the vegetative cells are responsible for the field activity of the biological agent.

B. subtilis R14 was isolated from the surface of cabbage leaves and has been shown to be effective as a biocontrol agent (Assis et al., 1996; 1997). Lipopeptides produced by this play a major role in the reduction of the incidence of the bacterial fruit blotch of melon and the black rot of crucifers observed in greenhouse and field trials (Monteiro et al., 2005; Santos et al., 2006).

\section{Aerobic cultivations}

Figure 1 and Figure 2 present the results obtained during cultivation under excess-oxygen availability at $30^{\circ} \mathrm{C}$ and $37^{\circ} \mathrm{C}$, respectively. Growth rate during the exponential phase at $30^{\circ} \mathrm{C}$ was half than at $37^{\circ} \mathrm{C}$ (data not shown), while the maximum biomass concentration reached was the same. The production of bioactive compounds was not detected during the exponential phase in either cases. This was not surprising, since microorganisms grow fast when nutrient are abundant and readily available, and antibiotic production nearly always takes place only after rapid growth has ceased.

Growth and sporulation are two means by which Bacillus ensures survival under all environmental conditions. In its natural environment, it is during the transition state that $B$. subtilis excretes several enzymes and bioactive compounds to degrade the complex substrates and ensures that other bacteria and fungi are prevented from invading its ecological niche. Sporulation is usually considered the last resort to be embarked upon when all other attempts to grow, compete and survive have been exhausted. In the bioreactor environment, to attain a rapid sporulation, a short stationary phase was planned by using a balanced $\mathrm{C} / \mathrm{N}$ ratio in the medium. As shown in Figures 1 and 2, due to the characteristic of the formulated medium, the transition from the exponential to stationary phase was rapid, and consequently, the production of bioactive compounds could not be detected in the post-exponential growth phase. A balanced $\mathrm{C} / \mathrm{N}$ ratio resulted in the depletion of glucose and ammonium sulphate concomitantly, and, as a last mean of survival, sporulation occurred in both the cases in response to exhaustion of these nutrients. At 24 hs of cultivation, the maximum spore concentration of $10^{8} \mathrm{CFU} / \mathrm{mL}$ was attained at $37^{\circ} \mathrm{C}$. Due to the slower growth rate, a lower spore concentration, around $10^{5} \mathrm{CFU} / \mathrm{mL}$, was observed at $30^{\circ} \mathrm{C}$ at the same time. 


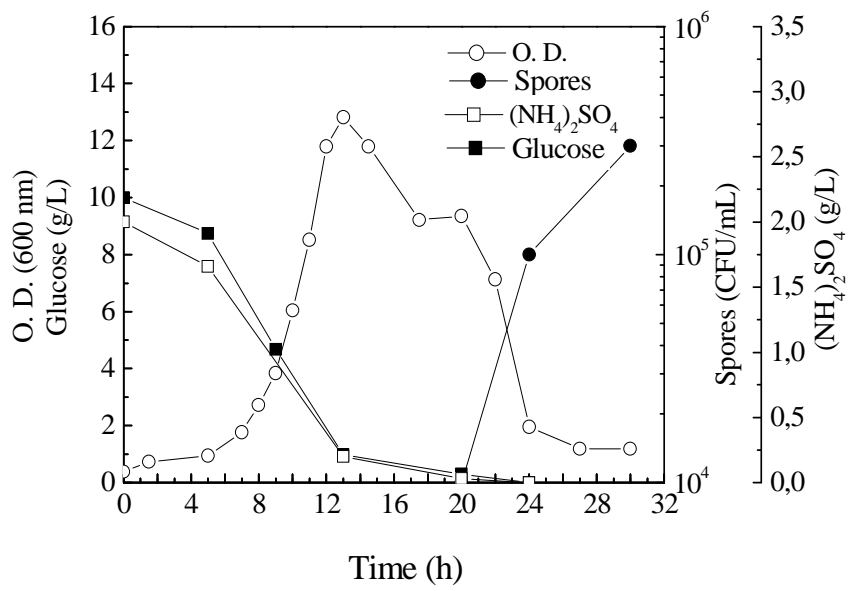

Figure 1 - Time course of cell growth, substrate consumption, and sporulation, during aerated cultivation of Bacillus subtilis $\mathrm{R} 14$ at $30^{\circ} \mathrm{C}$

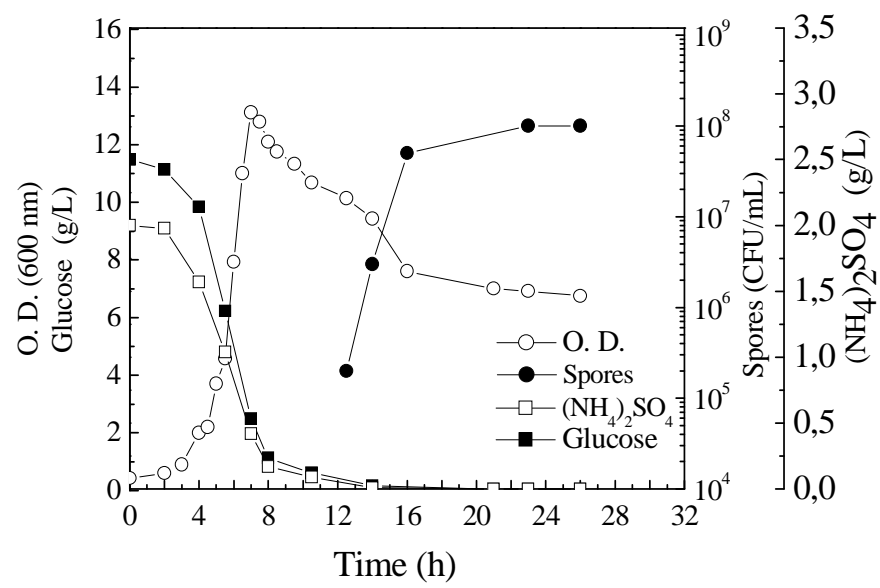

Figure 2 - Time course of cell growth, substrate consumption, and sporulation, during aerated cultivation of Bacillus subtilis $\mathrm{R} 14$ at $37^{\circ} \mathrm{C}$.

\section{Anaerobic cultivations}

B. subtilis, considered for a long time as a strict aerobe, can also grow anaerobically either by utilizing nitrate or nitrite as an electron acceptor or by fermentation in the absence of electron acceptors (Nakano and Hullet, 1997; Nakano and Zuber, 1998). To verify whether B. subtilis R14 could grow under strict anaerobic condition, cultures were carried out in anaerobic jars using minimal media containing ammonium sulphate and/or sodium nitrate (Fig. 3). Neither fermentation nor nitrate respiration could be observed under these conditions. After 72 hs of inoculation, no growth was observed in any case studied. However, these results were not unexpected. It has been shown that $B$. subtilis has a very inefficient glucose fermentation system, which requires the addition of pyruvate or mixture of amino acids to support growth on minimal medium (Nakano et al., 1997). 

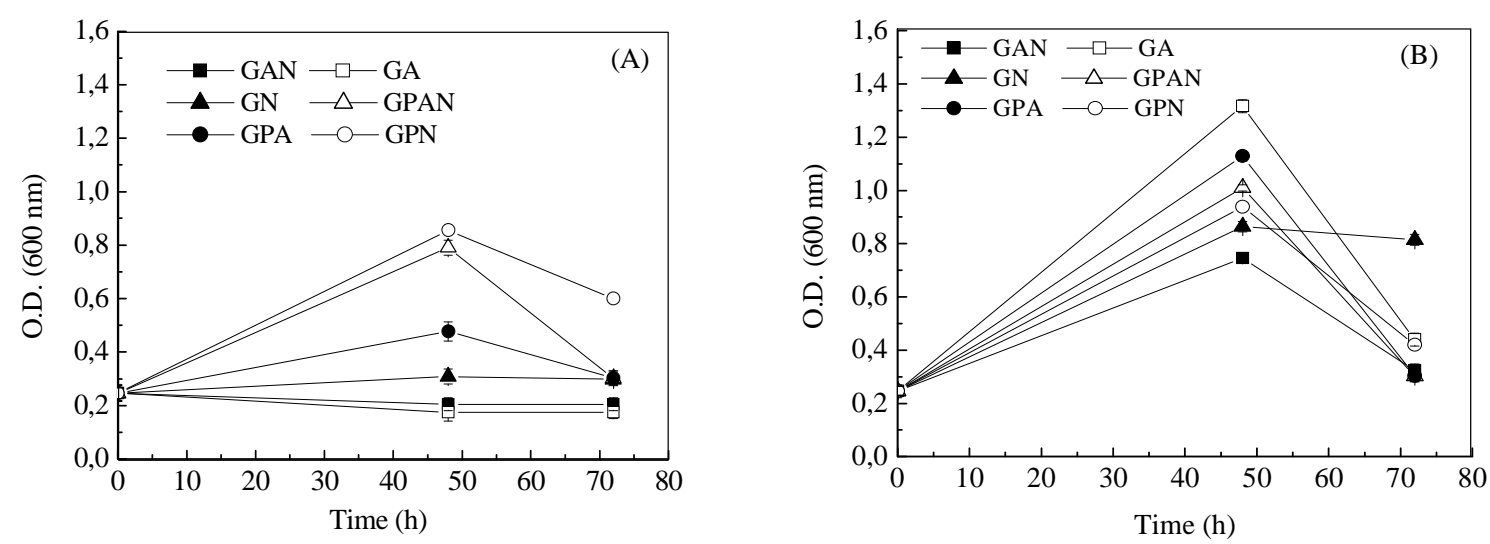

Figure 3 - Time course of cell growth of Bacillus subtilis R14 in different cultivation media at $37^{\circ} \mathrm{C}$ : (A) anaerobic growth and (B) aerobic growth. GAN - Glucose + ammonium sulphate + sodium nitrate sodium; GA - Glucose + ammonium sulphate; GN Glucose + sodium nitrate; GPAN - Glucose + sodium pyruvate + ammonium sulphate + sodium nitrate; GPA - Glucose + sodium pyruvate + ammonium sulphate; GPN Glucose + sodium pyruvate + sodium nitrate.

To study the influence of the addition pyruvate to the growth of $B$. subtilis R14 in anaerobiosis, sodium pyruvate was added to the minimum media used previously. In all of the cultivations carried out on medium containing glucose and pyruvate as carbon sources, microbial growth was detected (Fig. 3). Growth in the presence of pyruvate can be attributed to the induction of the gene that codifies the pyruvate dehydrogenase (PDH), which catalyzes the synthesis of acetyl-CoA from pyruvate (Nakano et al., 1997; Nakano and Zuber 1998; Nakano and Zuber, 2002). In the media containing sodium nitrate, higher yield on biomass was observed in relation to growth on media containing ammonium sulphate as the sole nitrogen source. When nitrate was present in the medium, it was reduced to nitrite, corresponding to an anaerobic respiration, which yields 36 to 38 ATP molecules (Ramos et al., 2000; Sonenshein, 2002). In the absence of nitrate, growth may occur by the fermentative pathway, in which energy is generated by phosphorylation at the substrate level (energy yield of 2 ATP molecules) (Nakano and Zuber, 1998).

\section{Oxygen-restricted cultivations}

Bacillus spp. are involved in the control of plant diseases through a variety of mechanisms of action, such as competition, systemic resistance induction, and antibiotics production. The mechanism of antibiosis has been shown to be one of the most important (Thomashow and Weller, 1996). Among several peptide antibiotics, Bacillus spp. produce lipopeptides, which are amphiphilic compounds with surfactant activity (Zuber et al., 1993). The production of both antimicrobial and surfactant activities occur during the growth of $B$. subtilis R14 on solid and liquid complex media (Monteiro et al., 2005). For this strain, it has been shown that antibiosis has a major role in the reduction, observed in greenhouse and field trials, of the incidence of black rot of crucifers and fruit blotch of melon.

The soil, a natural habitat for B. subtilis, contains numerous anaerobic microenvironments, and many genes required for antibiotic production by B. subtilis are induced by oxygen limitation (Nakano and Zuber, 2002). The soil also contains an abundant source of nitrate. To assess the influence of oxygen limitation and the presence of nitrate on the production bioactive compounds by B. subtilis R14, cultivations were carried out under oxygen limitation in different glucose media, containing ammonium sulphate, sodium nitrate or both nitrogen sources at $37^{\circ} \mathrm{C}$.

Figure 4 presents the results obtained during oxygen-limited cultivation on glucose and ammonium sulphate medium. After inoculation, the growth was unrestricted until less than $8 \mathrm{hs}$ of cultivation, after which growth followed a linear 
pattern, indicating that oxygen limitation took place. Growth ended after 50 hs of cultivation, when carbon and nitrogen were still available, but oxygen might be depleted. Growth could not proceed further since fermentation does not occur in anaerobiosis in minimal medium as shown in the anaerobic jar cultivation experiments. Increasing bioactive compound concentrations were detected throughout the oxygen-limited growth. At 75 hs of cultivation, a maximum bioactivity was observed $(\sim 21 \mathrm{~mm})$ when growth was already declining. The biomass yield on consumed glucose was much lower than under excess-oxygen cultivation, and sporulation was not observed under this restricting condition.

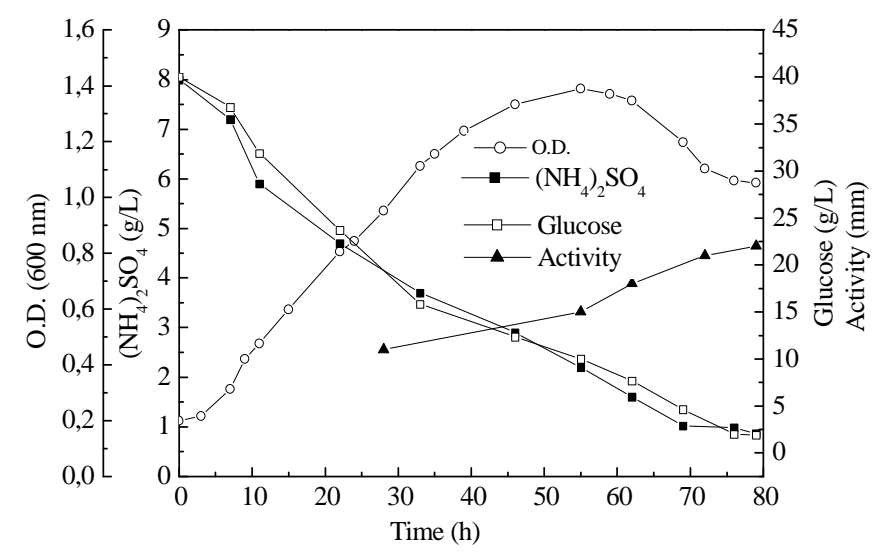

Figure 4 - Time course of cell growth, substrate consumption, and bioactive compound production, during oxygen-restricted cultivation of Bacillus subtilis R14 at $37^{\circ} \mathrm{C}$, with ammonium sulphate as sole nitrogen source.

Figure 5 shows the results on growth and product formation by $B$. subtilis R14 using glucose and sodium nitrate as the sole nitrogen source. A linear growth pattern was observed as when ammonium sulphate was present as the sole nitrogen source (Fig. 4), but a higher biomass yield was obtained. As in the previous case, growth proceeded for about $50 \mathrm{hs}$. The longer lag phase observed in this case could be attributed to the fact that the inoculum was grown on glucose and ammonium sulphate medium. The production of bioactive compounds was also observed during the restricted growth phase. The maximum activity $(\sim 25 \mathrm{~mm})$ was higher and attained earlier, at around $60 \mathrm{hs}$ of cultivation.

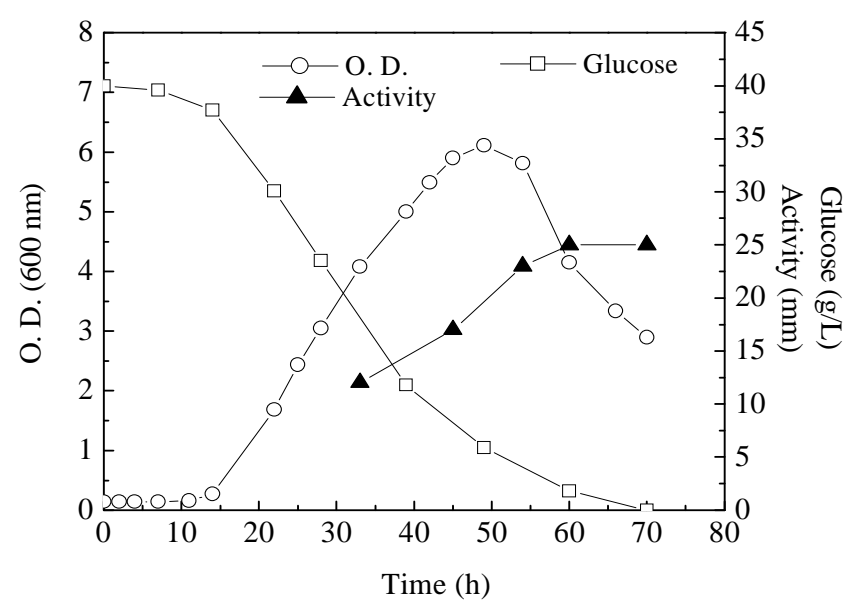

Figure 5 - Time course of cell growth, substrate consumption, and bioactive compound production, during oxygen-restricted cultivation of Bacillus subtilis R14 at $37^{\circ} \mathrm{C}$, with sodium nitrate as the sole nitrogen source. 
Figure 6 shows the results obtained when ammonium and nitrate were used together as nitrogen sources during oxygen limitation. Growth rate was enhanced when compared to the previous case. Growth ended before $30 \mathrm{hs}$ of cultivation, when ammonium was nearly depleted. The maximum biomass obtained was higher than that obtained with ammonium sulphate and lower than that obtained with sodium nitrate. This result could indicate that while ammonium was used solely as nitrogen source, nitrate might have been used as a final electron acceptor. Even though, the growth was not observed on this medium under anaerobic conditions, nitrate reductase has been isolated from B. subtilis cultured under low aeration (Nakano and Zuber, 1998). As in the two previous cases, bioactive compounds production occurred throughout the oxygen-limited growth.
At around 35 hs of cultivation, maximum bioactivity, equal to the one obtained with nitrate as sole nitrogen source, was already attained.

For one of the oxygen-restricted cultivations, the activity of the compounds produced by $B$. subtilis R14 was tested against other important phytopatogenic bacteria besides Agrobacterium tumefaciens. All the bacteria tested were sensitive to the compounds as shown in Table 2. The inhibition halos were similar or larger than those obtained for $X$. campestris pv. campestris and Acidovorax avenae subsp. citrulli, causal agents of the black rot of crucifers and the bacterial fruit blotch of melon, respectively, which have both shown to be efficiently controlled by $B$. subtilis R14 (Assis et al., 1996; 1997; Monteiro et al., 2005; Santos et al., 2006).

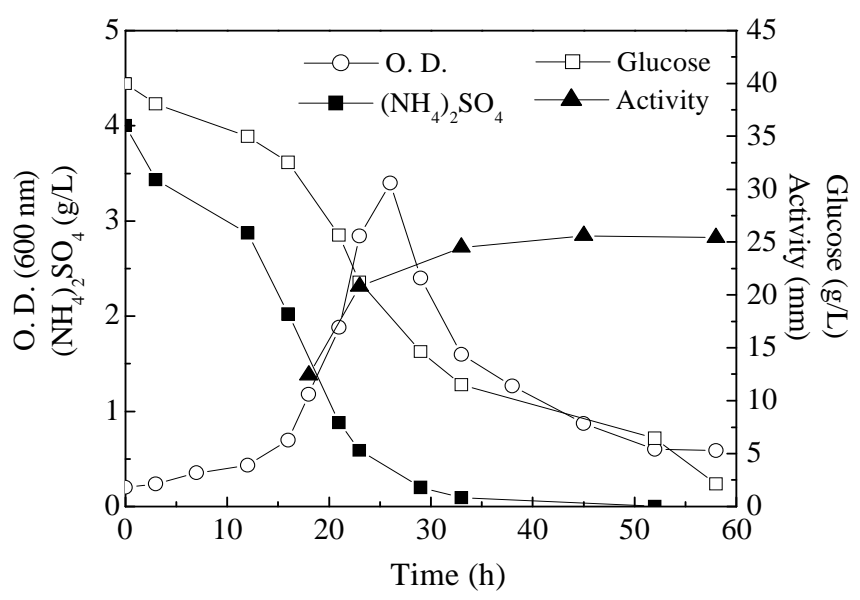

Figure 6 - Time course of cell growth, substrate consumption, and bioactive compound production, during oxygen-restricted cultivation of Bacillus subtilis R14 at $37^{\circ} \mathrm{C}$, with ammonium sulphate and sodium nitrate as nitrogen sources.

Table 2 - Activity of bioactive compounds produced by B. subtilis R14 during oxygen-limitation against phytopathogenic bacteria.

\begin{tabular}{lc}
\hline Microorganism & Halo (mm) \\
\hline Agrobacterium tumefaciens & $26.3 \pm 0.1$ \\
R. solanacearum RS103 bv.1 & $15.8 \pm 0.1$ \\
Pectobacterium carotovorum & $15.9 \pm 0.1$ \\
Xanthomonas campestris pv. viticola & $14.5 \pm 0.2$ \\
X. campestris pv. campestris & $13.6 \pm 0.2$ \\
Acidovorax avenae subsp. citrulli & $12.1 \pm 0.2$ \\
Erwinia amylovora & $11.8 \pm 0.2$ \\
Ralstonia solanacearum RS13 bv.1 & $11.0 \pm 0.1$ \\
\hline
\end{tabular}




\section{ACKNOWLEDGEMENT}

The authors are grateful to Fundação de Amparo à Ciência e Tecnologia do Estado de Pernambuco (FACEPE) and Coordenação de Aperfeiçoamento de Pessoal de Nível Superior (CAPES) for the financial support.

\section{RESUMO}

A fisiologia de B. subtilis R14 foi investigada em meio mínimo em condições de excesso e limitação de oxigênio. Crescimento e esporulação eficientes foram obtidas em culturas com excesso de oxigênio em meio contendo fontes de carbono e nitrogênio de fácil assimilação, que permitiram alta taxa de crescimento e alto rendimento em biomassa. Uma fase de transição curta, entre o crescimento exponencial e a esporulação, pode ser obtida pela formulação de um meio com razão $\mathrm{C} / \mathrm{N}$ balanceada. Sob limitação de oxigênio, mas em presença de nutrientes essenciais, B. subtilis R14 produziu compostos bioativos. Os compostos apresentaram atividade contra várias bactérias fitopatogênicas. Sob condição de anaerobiose, o microrganismo não cresceu, nem através de fermentação nem de respiração anaeróbica. A adição de piruvato ao meio permitiu o crescimento, tanto através de fermentação como de respiração anaeróbica. O conhecimento adquirido neste trabalho é relevante tanto para o projeto do processo de produção quanto para a formulação de um produto comercial eficiente para biocontrole.

\section{REFERENCES}

Agrios, G.N. (1997), Plant diseases caused by prokaryotes: bacteria and mollicutes. In- Plant pathology, ed. G.N. Agrios. Academic Press, New York

Assis, S.M.P.; Mariano, R.L.R.; Michereff, S.J.; Coelho, R.S.B. (1996), Biocontrol of Xanthomonas campestris pv. campestris on kale with Bacillus spp. and endophytic bacteria. In- Advances in biological control of plant disease, ed. T. Wenhua. China Agricultural University Press, Beijing
Assis, S.M.P.; Mariano, R.L.R.; Michereff, S.J.; Coelho, R.S.B. (1997), Antagonism of Bacillus spp. to Xantomonas campestris pv. campestris on cabbage phyloplane in the field. In- Proceedings of the Fourth International Workshop on Plant Growth-Promoting Rhizobacteria, eds. A. Ogoshi et al., Present Status and Future Prospects, Sapporo, 1997

Backman, P.A.; Wilson, M.; Murphy, J.F. (1997), Bacteria for biological control of plant diseases. InEnvironmentally safe approaches to crop disease control, eds. N.A. Rechcigl and J.E. Rechcigl. VCH, Weinheim

Chater, K.F.; Bibb, M.J. (1997), Regulation of bacterial antibiotic production. In- Biotechnology: products of secondary metabolism, eds. H.J. Rehm and G. Reed. $\mathrm{VCH}$, Weinheim

Emmert, E.A.B.; Handelsman, J. (1999), Biocontrol of plant disease: a (Gram-) positive perspective. FEMS Microbiol Lett., 171, 1-9

Fritze, D. (2004), Taxonomy of the genus Bacillus and related genera: the aerobic endospore-forming bacteria. Phytopathology, 94, 1245-1248

Jacobsen, B.J.; Zidack, N.K.; Larson, B.J. (2004), The role of Bacillus-based biological control agents in integrated pest management systems: plant diseases. Phytopathology, 94, 1272-1275

Kloepper, J.W. (1997), Current status and future trends in biocontrol research and development in the U. S.. In- Proceedings of the International Symposium of Clean Agriculture, Japan, 1997

Melo, I.S. (1998), Agentes microbianos de controle de fungos fitopatogênicos. In- Controle biológico, eds. I.S. Melo and J.L. Azevedo. Embrapa, Jaguariúna

Monteiro, L.; Mariano, R.L.R.; Souto-Maior, A.M. (2005), Antagonism of Bacillus spp. against Xanthomonas campestris pv. campestris. Brazilian Archives of Biology and Technology, 48, 23-29

Mulligan, C.N. (2004), Environmental applications for biosurfactants. Environ Pollut., 133, 183-198

Nascimento, A.R.P.; Mariano, R.L.R. (2004), Cancro bacteriano da videira: etiologia, epidemiologia e medidas de controle. Ciência Rural, 34, 301-307

Nakano, M.M.; Hulett, F.M. (1997), Adaptation of Bacillus subtilis to oxygen limitation. FEMS Microbiol Lett. 157, 1-7

Nakano, M.M.; Dailly, Y.P.; Zuber, P.; Clark, D.P. (1997), Characterization of anaerobic fermentative growth of Bacillus subtilis: identification of fermentation end products and genes required for growth. J Bacteriol., 179, 6749-6755

Nakano, M.M.; Zuber, P. (1998), Anaerobic growth of a "strict aerobe" (Bacillus subtilis). Annu Rev Microbiol., 52, 165-190 
Nakano, M.M.; Zuber, P. (2002), Anaerobiosis. InBacillus subtilis and its closets relatives: from genes to cells , eds. A.L. Sonenshein et al., American Society for Microbiology, Washington

Nelson, E.B. (2004), Microbial dynamics and interactions in the spermosphere. Annu Rev Phytopathol., 42, 271-309

Ongena, M.; Jacques, P.; Touré, Y.; Destain, J.; Jabrane, A.; Thonart, P. (2005), Involvement of fengycin-type lipopeptides in the multifaceted biocontrol potential of Bacillus subtilis. Appl Microbiol Biotechnol., 69, 29-38

Phillips, Z.E.V.; Strauch, M.A. (2002), Bacillus subtilis sporulation and stationary phase gene expression. Cell Mol Life Sci., 59, 392-402

Ramos, H.C.; Hoffmann, T.; Marino, M.; Nedjari, H.; Presecan-Siedel, E.; Dressen, O.; Glaser, P.; Jahn, D. (2000), Fermentative metabolism of Bacillus subtilis: physiology and regulation of gene expression. $J$ Bacteriol., 182, 3072-3080

Sales Júnior, R,. Menezes, J.B. (2001), Mapeamento das doenças fúngicas, bacterianas e viróticas do cultivo do melão no Estado do Rio Grande do Norte RN. Relatório técnico. Escola Superior de Agricultura de Mossoró, Mossoró

Santos, E.R.; Gouveia, E.R.; Mariano, R.L.R.; SoutoMaior, A.M. (2006), Controle biológico da manchaaquosa do melão causada por compostos bioativos produzidos por Bacillus spp. Summa Phytopathol., 32, 376-378

Schisler, D.A.; Slininger, P.J.; Behle, R.W.; Jackson, M.A. (2004), Formulation of Bacillus spp. for biological control of plant diseases. Phytopathology, 94, 1267-1271
Smith, I. (1993), Regulatory proteins that control lategrowth development. In- Bacillus subtilis and other Gram-positive bacteria, eds. A.L. Sonenshein et al. American Society for Microbiology, Washington

Sonenshein, A.L. (2002), The Kreb citric acid cycle. InBacillus subtilis and other Gram-positive bacteria, eds. A.L. Sonenshein et al. American Society for Microbiology, Washington

Thomashow, L.S.; Weller, D.M. (1996), Current concepts in the use of introduced bacteria for biological disease control: mechanisms and antifungal metabolites. In- Plant-Microbe Interactions, eds. G. Stacey and N.T. Keen. New York, Chapman and Hall, v. 1, p. 187-235

Zuber, P.; Nakano, M.M. Marahiel, M.A. (1993), Peptide antibiotics. In- Bacillus subtilis and other Gram-positive bacteria, eds. A.L. Sonenshein et al. American Society for Microbiology, Washington

Zuber, P.; Marahiel, M.A. (1997), Structure, function, and regulation of genes encoding multidomain peptide synthetases. In- Biotechnology of Antibiotics, ed. W.R. Strohl, 2nd edn. Marcel Dekker, New York

Received: October 19, 2007; Revised: April 07, 2008; Accepted: July 13, 2009. 